\title{
Feasibility of Web-based Teaching Materials that Accommodate Multiple Intelligences on Global Warming Materials
}

\author{
Winny Liliawati ${ }^{1}$, Taufik Ramlan Ramalis ${ }^{2}$, Annida Meida Zulika ${ }^{3}$ \\ \{winny@upi.edu ${ }^{1}$, taufik_lab.ipba@upi.edu ${ }^{2}$, annidameliazulika@upi.edu ${ }^{3}$ \} \\ Department of Physics Education, Indonesia University of Education, Indonesia, 40154 1,2, \\ Postgraduate of Physics Education, Indonesia University of Education, Indonesia, $40154^{3}$
}

\begin{abstract}
This study aims to examine the feasibility of web-based global warming teaching materials that accommodate multiple intelligences for high school students. The research method uses design-based research. The instrument is used as a web-based teaching material assessment sheet that accommodates multiple intelligences consisting of assessment sheets for aspects of content, media, and multiple intelligences. Validators were 12 experts consisting of 5 expert lecturers on content and multiple intelligences aspect, and 7 expert lecturers on media. The feasibility test was obtained using the Content Validity Ratio (CVR) equation and categorized. The results obtained CVR scores for the aspect of content 0.86 with the very appropriate category, the aspect of the media 0.69 with the very appropriate category, the aspect of compound intelligence 0.68 with the appropriate category. The conclusion is that web-based teaching materials with multiple intelligences oriented are very feasible to use.
\end{abstract}

Keywords: Web-based Teaching Materials, Multiple Intelligences, Content Validity Ratio

\section{Introduction}

Teaching materials are all forms of materials used to assist teachers in carrying out teaching and learning activities in the class [1], [2], [3]. Teaching materials have an important position in learning, namely as a representation of the teacher's explanation in front of the class. Teaching material occupies a position that determines the success of teaching and learning with the achievement of learning objectives and determines teaching and learning activities [4]. The existence of teaching materials, the learning objectives can be achieved properly. Learning occurs through interactions with people (teachers and peers) and teaching materials namely textbooks, workbooks, instructional software, web-based content, homework, projects, quizzes, and tests [5].

Teaching materials are used in the learning process of various supportive learning designs for example with the help of the internet during learning activities [6]. In the current era of information media development, it can be utilized to develop systematic and interesting teaching materials for students. Web-based teaching material is one of the current uses of information media. Web-based teaching materials are teaching materials that are designed in the form of a web in which there is content in the form of text, images, videos, sounds, animations or others [7]. The use of web-based teaching materials has two aspects to improve student learning, namely the first aspect of the availability of the selected material, the second aspect finds the 
relevance of the material with the quality of the existing assessment [7]. Teaching materials are selected according to students' interest in learning. It is known that students or individuals have different intelligence. Then the teaching material used must be adjusted to the type of intelligence of the students. For example, educators can present varied learning resources to represent each student's intelligence that has a different dominant intelligence.

According to Gardner [8], there are 8 types of intelligence, namely, logical intelligence mathematical, linguistic, visual-spatial, kinesthetic, musical, interpersonal, intrapersonal and naturalist possessed by humans. Intelligence is one of the main factors that determine the success and failure of students studying in school. Each student has a different type of intelligence. Preliminary studies conducted at one of the high schools around the city of Bandung showed the results that of the 34 students who were distributed with a compounded type questionnaire had different dominant intelligence. This proves that the types of intelligence students have varied so that teachers are required to adjust all aspects of learning so that the learning process becomes comfortable and conducive for students. Teaching materials used by students must also be able to represent each type of intelligence available so students with various types of intelligence do not feel difficulties in learning through the available teaching materials.

The existence of teaching materials related to Earth and Space Sciences is still very minimal. Lack of reading material for students causes an understanding of student concepts below. Often, students use internet learning resources to be able to add their insights. Learning resources from the internet can be one way to improve student understanding. However, sometimes these internet sources are not by the current curriculum and under student interests. So, it is important to provide and facilitate students to learn from internet sources that have been validated and known for their truth.

\section{Material and Methods}

This research is development research that was designed with the Design Based Research (DBR) approach to develop web-based teaching materials with multiple intelligences oriented on global warming material for high school students. There are 4 stages in DBR [9] namely identification and analysis of problems, designing solutions, repetitive cycles in testing and refining designs, reflection to produce design and implementation principles. The first stage is the identification and analysis of problems, which is the initial stage of the study by identifying and analyzing the problem to be studied, starting from what problems become anxious himself, what are the factors that cause these problems, and what can be done to overcome these problems. The second stage is the design of solutions, where the solution will be designed based on the background of the problem that occurs to get the results of the research objectives. The third is the repetitive cycle in the tests carried out, so that it will produce the best final design. At this stage, the validation of teaching materials is carried out narrow trials and extensive tests. The last stage is the final reflection to produce design principles in this study. This article only discusses some of the results in stage 3 of the DBR, which is testing the feasibility of web-based teaching materials.

Analysis of the feasibility of teaching materials or content validity uses Content Validity Ratio (CVR) [10]. The validity of the test used in this study is the content validity by asking judgment from a group of experts of 12 experts to determine the suitability of the aspects of content, multiple intelligences, and the media. Content validity is done using the formula Content Validity Ratio (CVR). CVR is a content validation approach to determine the suitability 
of the question items with components that are measured based on expert judgment [10]. Answer the question using the CVR method. The instrument feasibility of teaching materials given to the validator consists of 4 choices of answers that are very appropriate, appropriate, not appropriate and not very appropriate. In calculating the data analysis using CVR, the answers are very appropriate and accordingly written (S) and the answers are not appropriate and very not suitable written with (TS). After getting the score then the score is processed using the CVR calculation method. The instrument can be declared valid if the calculated CVR value obtained is higher than the critical CVR value. Critical CVR values based on the Schipper Table [10] are presented in the following Table 1.

Table 1. Minimum CVR value for various numbers of validator.

\begin{tabular}{cccc}
\hline Number of Expert & $\begin{array}{c}\text { Minimum CVR } \\
\text { Value }\end{array}$ & Number of Expert & $\begin{array}{c}\text { Minimum CVR } \\
\text { Value }\end{array}$ \\
\hline 5 & 0,736 & 13 & 0,456 \\
6 & 0,672 & 14 & 0,440 \\
7 & 0,622 & 15 & 0,425 \\
8 & 0,582 & 20 & 0,368 \\
9 & 0,548 & 25 & 0,329 \\
10 & 0,520 & 30 & 0,300 \\
11 & 0,496 & 35 & 0,287 \\
12 & 0,475 & 40 & 0,260 \\
\hline
\end{tabular}

Then the results are categorized by the CVR category as in Table 2.

Table 2. CVR Score Categories.

\begin{tabular}{cc}
\hline CVR Score Range & Category \\
\hline $0,68-1,00$ & Very appropriate \\
$0,34-0,67$ & Appropriate \\
$0,00-0,33$ & It is not in accordance with \\
\hline
\end{tabular}

\section{Result and Discussion}

The feasibility of web-based teaching materials in the material aspects and compound intelligence was assessed by 5 expert lecturers, while for the feasibility of web-based teaching materials in the media aspect, it was assessed by 7 expert lecturers. For the material aspects and multiple intelligences, the rating scale starts from very appropriate, appropriate, less appropriate and very less appropriate. As for the media aspect, the rating scale starts from very good, good, not good, to very bad. Here are the results of expert judgment for the feasibility of teaching materials in Table 3: 
Table 3. The results of the assessment from the validator are processed with CVR on the material aspects.

\begin{tabular}{|c|c|c|c|c|}
\hline No & Indicators & $n_{\mathrm{o}}$ & $\mathrm{N}$ & CVR Score \\
\hline 1. & Conformity between $\mathrm{BC}$ and indicators/objectives & 4 & 5 & 0,6 \\
\hline 2. & $\begin{array}{l}\text { The suitability of each indicator with the content } \\
\text { description }\end{array}$ & 4 & 5 & 0,6 \\
\hline 3. & Up to date content & 5 & 5 & 1 \\
\hline 4. & Accurate content, free from misconceptions & 4 & 5 & 0,6 \\
\hline 5. & $\begin{array}{l}\text { Material structure and organization are arranged } \\
\text { logically and coherently }\end{array}$ & 5 & 5 & 1 \\
\hline 6. & The style of exposure is interesting to read & 4 & 5 & 0,6 \\
\hline 7. & The written language used is easy to understand & 5 & 5 & 1 \\
\hline 8. & $\begin{array}{l}\text { Description of teaching material builds students' } \\
\text { conceptual understanding }\end{array}$ & 5 & 5 & 1 \\
\hline 9. & $\begin{array}{l}\text { Learning and evaluation activities according to } \\
\text { indicators or objectives }\end{array}$ & 4 & 5 & 0,6 \\
\hline 10. & $\begin{array}{l}\text { The evaluation questions found in the teaching material } \\
\text { are by the subject matter }\end{array}$ & 5 & 5 & 1 \\
\hline 11. & $\begin{array}{l}\text { The evaluation questions are formulated so that they do } \\
\text { not confuse students }\end{array}$ & 5 & 5 & 1 \\
\hline 12. & $\begin{array}{l}\text { Evaluation questions have represented every discussion } \\
\text { in the existing chapters }\end{array}$ & 4 & 5 & 0,6 \\
\hline 13. & $\begin{array}{l}\text { Teaching material developed using symbols and SI units } \\
\text { consistently }\end{array}$ & 4 & 5 & 0,6 \\
\hline 14. & $\begin{array}{l}\text { The concept of science is integrated with environmental } \\
\text { components and social problems }\end{array}$ & 5 & 5 & 1 \\
\hline 15. & Content suitable for the age level of students & 5 & 5 & 1 \\
\hline 16. & $\begin{array}{l}\text { The language used is appropriate, effective, easy to } \\
\text { understand and under EYD }\end{array}$ & 5 & 5 & 1 \\
\hline 17. & $\begin{array}{l}\text { The material provides a context that is relevant to the } \\
\text { student environment }\end{array}$ & 5 & 5 & 1 \\
\hline 18. & $\begin{array}{l}\text { Train students' skills in using their knowledge in various } \\
\text { situations }\end{array}$ & 5 & 5 & 1 \\
\hline 19. & $\begin{array}{l}\text { The description of the material is associated with prior } \\
\text { student knowledge }\end{array}$ & 5 & 5 & 1 \\
\hline 20. & $\begin{array}{l}\text { Content descriptions are always associated with their } \\
\text { application in everyday technology }\end{array}$ & 5 & 5 & 1 \\
\hline
\end{tabular}

\begin{tabular}{ccc}
\hline $\mathrm{n}_{\mathrm{o}}$ & $\mathrm{N}$ & CVR Score \\
\hline 93 & 100 & 0,86 \\
& Category & Very Appropriate \\
\hline
\end{tabular}


The feasibility test of teaching materials is assessed using the CVR approach, which is the content validation approach to determine the suitability of the question items with the measured component. For material aspects, the results obtained as the above data. Based on the data in Table 4 it can be seen that the due diligence in the material aspect consists of 20 questions. Based on calculations using the CVR score formula by counting the number of respondents who stated under the total number of respondents, the CVR score for the material aspects is 0.86 . This value is in the range of CVR scores in the very appropriate category. This score is then compared with the critical CVR value based on the Schipper Table. Based on the number of experts namely 5 validators, the minimum CVR value is 0.736 . By comparing the CVR scores obtained with a minimum CVR of $0.86>0.736$, the instrument can be declared valid.

Table 4. The results of the assessment from the validator are processed with CVR on the media aspect.

\begin{tabular}{llccc}
\hline No & \multicolumn{1}{c}{ Indicators } & $\mathrm{n}_{\mathrm{o}}$ & $\mathrm{N}$ & CVR Score \\
\hline 1. & Use of language on the web & 7 & 7 & 1 \\
2. & Readability of the text & 7 & 7 & 1 \\
3. & Image display quality & 4 & 7 & 0,14 \\
4. & Clarity of web instructions & 5 & 7 & 0,43 \\
5. & Clarity of sound in video and music & 7 & 7 & 1 \\
6. & The button works fine & 6 & 7 & 0,71 \\
7. & Appropriate font selection & 6 & 7 & 0,71 \\
8. & Quality display animation / video & 6 & 7 & 0,71 \\
9. & The overall appearance of the web & 6 & 7 & 0,71 \\
10. & Ease of accessing the web & 6 & 7 & 0,71 \\
11. & The clarity in assignment instructions & 5 & 7 & 0,43 \\
& & 65 & 77 & 0,69 \\
& & & & (Very Appropriate) \\
\hline
\end{tabular}

Based on calculations using the CVR score formula by counting the number of respondents who stated by the total number of respondents, the CVR score for the media aspect is 0.688 . This value is in the range of CVR scores in the very appropriate category. This score is then compared with the critical CVR value based on the Shipper Table. Based on the number of experts namely 7 validators, the minimum CVR value is 0.622 . By comparing the CVR scores obtained with a minimum CVR of $0.69>0.622$, the instrument can be declared valid.

For the results (Table 5) of the validation of the feasibility of web-based teaching materials on multiple intelligence aspects, the assessment questionnaire was prepared based on the order of appearance, starting from the initial appearance of the web, global warming pages, pages causing global warming, pages due to global warming, and countermeasures pages. For the aspect of multiple intelligences, the total CVR score of 0.68 is in the very appropriate category.

Based on the feasibility test of teaching materials that have been carried out by the validator, the overall evaluation results are under the CVR value of 0.69 for the media aspect and the CVR value of 0.87 for the material aspect. Both CVR values are in the high category. This can be interpreted that the teaching materials developed are categorized very well. This is because physics teaching materials are still very rare, especially in the matter of global warming which is oriented to multiple intelligences. As in the most recent research by Rahmansyah [11] who compiled integrated earth and space science teaching materials that accommodate students' 
multiple intelligences stated that integrated teaching materials can help teachers in creating comprehensive learning. The purpose of earth and space science teaching materials compiled by Rahmansyah [11] is to provide mastery of the integrated earth and space science concept and to accommodate multiple intelligences. Thus, according to the validator, it can be concluded that the teaching material developed is feasible to be used by students in learning. The suggestions submitted by the validator include the quality and image size that is too small and broken, and then the video quality is less than the maximum when in full screen. Besides, there are still some errors in writing and understanding the concept so it needs to be corrected. The validator also suggests adding guidance pages to make it easier for students to carry out the learning process through the website.

Table 5. The results of the assessment from the validator are processed by CVR on the aspect of multiple intelligences.

\begin{tabular}{clcccc}
\hline No & Multiple Intelligences & $\mathrm{n}_{\mathrm{o}}$ & $\mathrm{N}$ & CVR Score & Category \\
\hline 1. & Visual Spatial & 66 & 75 & 0,76 & Very Appropriate \\
2. & Musical & 19 & 25 & 0,52 & Appropriate \\
3. & Verbal Linguistics & 17 & 20 & 0,7 & Very Appropriate \\
4. & Mathematical logical & 8 & 10 & 0,6 & Appropriate \\
5. & Kinesthetic & 4 & 5 & 0,6 & Appropriate \\
6. & Intrapersonal & 8 & 10 & 0,6 & Appropriate \\
7. & Interpersonal & 4 & 5 & 0,6 & Appropriate \\
8. & Naturalist & 4 & 5 & 0,6 & Appropriate \\
& Score CVR Total & 130 & 155 & 0,68 & Very Appropriate \\
\hline
\end{tabular}

\section{Conclusion}

Web-based teaching materials oriented on multiple intelligences on global warming material in high schools based on expert validation on aspects of the material, media and orientation on multiple intelligences are appropriate for use by students with excellent categories.

\section{References}

[1] Maryati, A.M.: Pengembangan Buku Nonteks Pelajaran IPA Terpadu Menggunakan Model Webbed dengan Tema Kesehatan. Tesis Universitas Pendidikan Indonesia (2016)

[2] Majid, A.: Perencanaan Pembelajaran. PT. Remaja Rosdakarya. Bandung (2007)

[3] Pannen, P., Mustafa, D., \& Sekarwinahyu, M.: Kontruktivisme dalam Pembelajaran. Depdiknas. Jakarta (2001)

[4] Hamalik, O.: Manajemen Pengembangan Kurikulum. PT. Remaja Rosdakarya. Bandung (2007)

[5] Chingos, M.M. \& Grover J.: Choosing Blindly Instructional Materials, Teacher Effectiveness, and the Common Core. Brown Center on Education Policy at Brookings. 4 (10) (2012) 
[6] Garofalakis, J.D, Lagiou, E.V., \& Plessas, A.P.: Use of Web 2.0 Tools for Teaching Physics in Secondary Education. International Journal of Information and Education Technology, 3 (1) (2013)

[7] Orhun, E.: Web Based Learning Materials for Higher Education. The Merlot Repository. The Turkish Online Journal of Educational Technology. 3 (10) (2004)

[8] Gardner, H.: Frame of Mind the Theory of Multiple Intelligences. NYC. Basic books 440 pp (2011)

[9] Amiel, T \& Reeves, T.C.: Design-Based Research and Educational Technology. Rethinking Technology and the Research Agenda. Educational Technology \& Society, 111 (4) (2008)

[10] Wilson, F.R., Pan, W., \& Schumsky, D.A.: Recalculation of the Critical Values for Lawshe's Content Validity Ratio. Measurement and Evaluation in Counselling and Development. 45 (197) (2012) [11] Rahmansyah, M.A., Liliawati, W., Utama, J.A., \& Ramalis, T.R: Penyusunan Bahan Ajar IPBA Terintegerasi yang Mengakomodasi Kecerdasan Majemuk untuk Meningkatkan Penguasaan Konsep Struktur Bumi pada Siswa SMP. Prosiding Simposium Nasional. Bandung (2015) 